EXTENDED REPORT

\title{
Macrophage specificity of three anti-CD68 monoclonal antibodies (KP1, EBM1 1, and PGM1) widely used for immunohistochemistry and flow cytometry
}

\author{
E Kunisch, R Fuhrmann, A Roth, R Winter, W Lungershausen, R W Kinne
}

Ann Rheum Dis 2004;63:774-784. doi: 10.1136/ard.2003.013029

See end of article for authors' affiliations

Correspondence to: Dr R W Kinne, Experimental Rheumatology Unit, Friedrich Schiller University Jena, Hans-Knöll-Str 2, D-07745 Jena, Germany; raimund.w.kinne@ rz.uni-jena.de

Accepted

9 September 2003
Objectives: To investigate the specificity of three anti-CD68 monoclonal antibodies (mAbs) for macrophages $(\mathrm{M} \phi)$ in immunohistochemistry $(\mathrm{IHC})$ and flow cytometry (FACS).

Methods: IHC was performed on cryostat sections of rheumatoid arthritis (RA) and osteoarthritis (OA) synovial membranes using the anti-CD68 mAbs KP1, EBM1 1, and PGM1, and the fibroblast (FB) markers CD90 and prolyl 4-hydroxylase. Expression of CD68 was also analysed by FACS on the monocytic cell lines THP-1 and U937, as well as on synovial fibroblasts (SFB), skin FB, and gingival FB (both surface and intracellular staining).

Results: In IHC, there was an overlap between CD68 (mAbs KP1 and EBM1 1) and the FB markers CD90/ prolyl 4-hydroxylase in the lining layer, diffuse infiltrates, and stroma of RA and OA synovial membranes. In FACS analysis of THP-1 and U937 cells, the percentage of cells positive for the anti-CD68 mAbs KP1 and EBM 11 progressively increased from surface staining of unfixed cells, to surface staining of pre-fixed cells, to intracellular staining of the cells. Upon intracellular FACS of different FB, nearly all cells were positive for KP1 and EBM1 1, but only a small percentage for PGM1. In surface staining FACS, a small percentage of $F B$ were positive for all three anti-CD68 mAbs.

Conclusion: An overlap between CD68 (mAbs KP1 or EBM11) and the FB markers CD90 or prolyl 4hydroxylase may prevent unequivocal identification of $M \phi$ in synovial tissue by $\mathrm{IHC}$ or in monocytic cells and FB upon intracellular FACS. This may be due to sharing of common markers by completely different cell lineages.
$\mathrm{R}$ heumatoid arthritis (RA) is a chronic inflammatory joint disease, ultimately leading to destruction of joint cartilage and bone. ${ }^{1}$ Joint destruction in RA is perpetuated by an aggressive, invasive pannus tissue, a vascular and fibrous granulation tissue consisting of macrophages $(\mathrm{M} \phi)$, synovial fibroblasts (SFB), $\mathrm{T}$ lymphocytes, and $\mathrm{B}$ lymphocytes/plasma cells. Immunotyping with specific antibodies has an important role in identifying and localising each cell type in tissue specimens by immunohistochemistry (IHC) and in characterising the purity of cell populations isolated from the synovial membrane (SM). T cells are easily and unequivocally detected by their expression of CD3, a molecule co-expressed with the $\mathrm{T}$ cell receptor in an obligatory fashion. For FB, several markers have been described-for example, prolyl 4-hydroxylase, ${ }^{2}$ CD90/Thy-1, or CD55. ${ }^{4}$ For immunotyping of $\mathrm{M} \phi$, monoclonal antibodies (mAbs) directed against different epitopes of CD68 are widely used markers.

$\mathrm{M} \phi$ play a critical role in the course of RA owing to their abundance in the inflamed SM and at the cartilage-pannus junction and to their activation status (as shown by overexpression of major histocompatibility complex class II (MHC II) molecules, proinflammatory cytokines, and matrix degrading enzymes). ${ }^{6}$ Also, articular destruction correlates with the density of synovial $\mathrm{M} \phi$ (as assessed by CD68 staining $)^{7}$; this density, in turn, is reduced after successful antirheumatic treatment. ${ }^{8-10}$

CD68 (the human homologue of mouse macrosialin) is a heavily glycosylated, $110 \mathrm{kDa}$ membrane protein; its transcription is regulated by a promoter containing multiple GGAA sequences instead of a TATA box or an INR sequence. ${ }^{11}$ CD68 is closely related to the family of lysosomal associated, mucin-like membrane proteins (lamps). Although CD68 is predominantly located in lysosomal membranes, a small fraction is also found on the cell surface. ${ }^{12}{ }^{13}$ Although the biological function of CD68 has not been fully defined, CD68 serves as a scavenger receptor for oxidised low densitylipoprotein ${ }^{14}$ and may also be involved in cell-cell interactions. ${ }^{1}$

Although prolyl 4-hydroxylase is widely used as a FB marker and CD14/CD68 are employed as M $\phi$ markers, their specificity for the respective cell type remains to be established. Prolyl 4-hydroxylase, a tetramer consisting of two $\alpha$ and $\beta$ subunits, shares the $\beta$ subunit with disulphide isomerase, a multifunctional polypeptide expressed in many different cell types. ${ }^{15}$ Therefore, the specificity of the selected anti-prolyl 4-hydroxylase mAbs has to be carefully checked. On the other hand, the monocyte/M $\phi$ marker CDI4 is also found on gingival FB isolated from inflamed gingiva, ${ }^{16}$ and CD68 is expressed in retinal epithelial cells, ${ }^{17}$ osteoblasts, ${ }^{18}$ and FB-like cells from the bone marrow. ${ }^{19}$

This study therefore aimed at further defining the usefulness of CD68 as a reliable monocyte/M $\phi$ marker for IHC and flow cytometry (FACS). CD68 expression was compared with the expression of other $\mathrm{M} \phi$ and $\mathrm{FB}$ markers by IHC in sections of the SM (single and double labelling), as

Abbreviations: DMEM, Dulbecco's modified Eagle's medium; FACS, fluorescence activated cell sorter; FB, fibroblast(s); FCS, fetal calf serum; $\mathrm{IHC}$, immunohistochemistry; JT, joint trauma; $\mathrm{mAb}$, monoclonal antibody; $M \phi$, macrophages; OA, osteoarthritis; PBS, phosphate buffered saline; PFA, paraformaldehyde; RA, rheumatoid arthritis; RT room temperature; SSC, sodium citrate/sodium chloride; SM, synovial membrane 
well as in isolated SFB, skin FB, gingival FB, and monocytic cell lines by FACS (surface and intracellular staining).

\section{PATIENTS AND METHODS \\ Patients}

Synovial tissue was obtained from patients with RA and osteoarthritis (OA) during open joint replacement surgery or arthroscopic synovectomy at the Clinic of Orthopaedics, Eisenberg, Germany. The patients were classified according to the American College of Rheumatology criteria $^{20}$ (table 1). Synovial tissue from patients with joint trauma (JT) was obtained from the Department of Traumatology, Friedrich Schiller University, Jena, Germany. The study was approved by the ethics committee of the Friedrich Schiller University, Jena, Germany. For IHC, synovial tissue was embedded in Tissue freezing medium (Leica Instruments, Nussloch, Germany), immediately frozen in isopentane (Merck, Darmstadt, Germany) cooled in liquid nitrogen, and stored at $-70^{\circ} \mathrm{C}$. The remaining tissue was placed in cell culture medium at room temperature (RT) and subjected to digestion within 2 hours.

\section{Immunohistochemistry}

IHC was performed using $5 \mu \mathrm{m}$ cryostat sections of RA and OA synovial membranes. Sections were fixed with acetone for 10 minutes at RT and then air dried. Alternatively, sections were fixed for 1 hour with $4.0 \%$ paraformaldehyde (PFA; Fluka, Steinheim, Germany)/phosphate buffered saline (PBS; $137 \mathrm{mM} \mathrm{NaCl} ; 2.68 \mathrm{mM} \mathrm{KCl} ; 8.1 \mathrm{mM} \mathrm{Na} \mathrm{HPO}_{4}$, $1.76 \mathrm{mM} \mathrm{KH}_{2} \mathrm{PO}_{4}$; all Roth, Karlsruhe, Germany), followed by an incubation step with $1 \times$ sodium citrate/sodium chloride (SSC; $150 \mathrm{mM} \mathrm{NaCl}, 15 \mathrm{mM}$ Na citrate, pH 7.0) at $55^{\circ} \mathrm{C}$ for 20 minutes. All subsequent steps were performed at RT in a humid chamber. Sections were incubated for 20 minutes with $0.03 \% \mathrm{H}_{2} \mathrm{O}_{2} / \mathrm{PBS}$ to inactivate endogenous peroxidase, followed by a blocking step with $10 \%$ horse serum/PBS for 20 minutes at RT. The specific antibodies (table 2), diluted in PBS/10\% horse serum, were added for 30 minutes. For immunohistochemical detection, sections were incubated with a peroxidase coupled rabbit antimouse antibody (Dako, Hamburg, Germany) for 30 minutes. The peroxidase was disclosed using the Sigma Fast

Table 1 Clinical characteristics of the patients at the time of synovectomy/sampling

\begin{tabular}{|c|c|c|c|c|c|c|c|c|}
\hline Patient & $\begin{array}{l}\text { Sex/age } \\
\text { (years) }\end{array}$ & $\begin{array}{l}\text { Disease duration } \\
\text { (years) }\end{array}$ & RF & $\begin{array}{l}\text { ESR } \\
(\mathrm{mm} / 1 \mathrm{st} h)\end{array}$ & $\begin{array}{l}\mathrm{CRP}^{*} \\
(\mathrm{mg} / \mathrm{ml})\end{array}$ & $\begin{array}{l}\text { No of ARA } \\
\text { criteria (RA) }\end{array}$ & Assay & Concomitant drug treatment \\
\hline \multicolumn{9}{|c|}{$\begin{array}{l}\text { Synovial fibroblasts } \\
\text { Rheumatoid arthritis (RA) }\end{array}$} \\
\hline EB26 & $M / 60$ & 20 & + & 68 & 68.6 & 4 & $\mathrm{IHC} / \mathrm{FI}$ & NSAIDs, SSZ, steroids \\
\hline EB27 & $F / 80$ & 5 & + & 40 & 39.3 & 6 & $\mathrm{IHC} / \mathrm{FI}$ & NSAIDs, MTX, steroids \\
\hline EB35 & $F / 65$ & 25 & - & 62 & 53.4 & 7 & $\mathrm{IHC} / \mathrm{FI}$ & NSAIDs, MTX, SSZ, steroids \\
\hline EB40 & $F / 64$ & 24 & + & 18 & 2.9 & 4 & $\mathrm{FI}$ & NSAIDs, MTX, steroids \\
\hline EB41 & $F / 63$ & 17 & + & 34 & 8.2 & 4 & $\mathrm{FI}$ & NSAIDs, SSZ, steroids \\
\hline EB42 & $F / 71$ & 44 & + & 50 & 35.8 & 6 & $\mathrm{FI}$ & NSAIDs, steroids \\
\hline EB50 & $F / 46$ & 1 & - & 16 & 5.5 & 4 & $\mathrm{FS} / \mathrm{FI}$ & NSAIDs, MTX \\
\hline EB52 & $M / 77$ & 5 & + & 45 & 38.5 & 6 & FS & NSAIDs \\
\hline EB53 & $F / 48$ & 34 & + & 2 & $<5$ & 6 & FS & MTX, steroids \\
\hline EB58 & $\mathrm{F} / 74$ & 5 & + & 12 & 12.2 & 5 & FS & NSAIDs, MTX, steroids \\
\hline \multicolumn{9}{|c|}{ Osteoarthritis (OA) } \\
\hline EB11 & $F / 46$ & 5 & - & 9 & 8.2 & 0 & $\mathrm{IHC} / \mathrm{FI}$ & None \\
\hline EB18 & $F / 68$ & 3 & - & 9 & $<5$ & 1 & $\mathrm{IHC} / \mathrm{FI}$ & None \\
\hline EB24 & $F / 71$ & 8 & - & 29 & $<5$ & 0 & $\mathrm{IHC} / \mathrm{FI}$ & NSAIDs \\
\hline EB29 & $F / 76$ & 2 & - & 13 & $<5$ & 1 & $\mathrm{Fl}$ & NSAIDs \\
\hline EB48 & $M / 70$ & 2 & - & 10 & $<5$ & 0 & $\mathrm{FS} / \mathrm{FI}$ & NSAIDs \\
\hline EB49 & $M / 71$ & 1 & - & 10 & $<5$ & 0 & $\mathrm{FS} / \mathrm{FI}$ & NSAIDs \\
\hline EB51 & $F / 72$ & 2 & - & 15 & $<5$ & 0 & $\mathrm{FS} / \mathrm{FI}$ & NSAIDs \\
\hline EB57 & $M / 73$ & 5 & - & 6 & $<5$ & 0 & FS & NSAIDs \\
\hline J4 & $F / 65$ & 10 & ND & 6 & 7.7 & 0 & $\mathrm{Fl}$ & NSAIDs, steroids \\
\hline J5 & $\mathrm{F} / 58$ & 10 & ND & ND & ND & 0 & $\mathrm{FI}$ & NSAIDs \\
\hline \multicolumn{9}{|c|}{$\begin{array}{l}\text { Skin fibroblasts } \\
\text { Rheumatoid arthritis }\end{array}$} \\
\hline EB20 & $M / 75$ & 0.75 & + & 29 & 22.4 & 6 & $\mathrm{FI}$ & NSAIDs, SSZ, steroids \\
\hline EB25 & $F / 67$ & 2 & + & 18 & $<5$ & 6 & $\mathrm{FI}$ & NSAIDs, MTX, steroids \\
\hline EB26 & $M / 60$ & 20 & + & 68 & 68.6 & 4 & $\mathrm{FI}$ & NSAIDs, steroids, SSZ \\
\hline EB27 & $F / 80$ & 5 & + & 40 & 39.3 & 6 & $\mathrm{FI}$ & NSAIDs, MTX, steroids \\
\hline EB86 & $F / 79$ & 20 & + & 14 & 6.5 & 6 & FS & NSAIDs, MTX, steroids \\
\hline EB87 & $F / 65$ & 12 & + & 50 & 106.7 & 5 & FS & NSAIDs \\
\hline \multicolumn{9}{|c|}{ Osteoarthritis } \\
\hline EB18 & $F / 68$ & 3 & - & 9 & $<5$ & 1 & $\mathrm{FI}$ & None \\
\hline EB21 & $F / 76$ & 1 & - & 38 & 27.4 & 0 & $\mathrm{FI}$ & None \\
\hline EB22 & $F / 76$ & 2 & - & 30 & $<5$ & 0 & $\mathrm{FI}$ & NSAIDs \\
\hline EB24 & $F / 71$ & 8 & - & 29 & $<5$ & 0 & $\mathrm{FI}$ & NSAIDs \\
\hline $\mathrm{J} 5$ & $\mathrm{~F} / 58$ & 10 & ND & ND & ND & 0 & $\mathrm{FI}$ & NSAIDs \\
\hline EB82 & $M / 62$ & 2 & - & 10 & $<5$ & 0 & FS & NSAIDs \\
\hline EB83 & $M / 77$ & 2 & - & 10 & $<5$ & 0 & FS & NSAIDs \\
\hline EB85 & F/73 & 3 & - & 23 & $<5$ & 0 & FS & None \\
\hline \multicolumn{9}{|l|}{ Normal } \\
\hline LZ1 & $\mathrm{F} / 43$ & 0 & ND & ND & ND & 0 & $\mathrm{FI}$ & None \\
\hline LZ2 & $\mathrm{F} / 2$ & 0 & ND & ND & ND & 0 & $\mathrm{FI}$ & None \\
\hline LZ3 & $F / 2$ & 0 & ND & ND & ND & 0 & $\mathrm{FI}$ & None \\
\hline
\end{tabular}

$\mathrm{RF}$, rheumatoid factor; ND, not determined; ESR, erythrocyte sedimentation rate; CRP, C reactive protein; *normal range $<5 \mathrm{mg} / \mathrm{l}$; ARA, American Rheumatism Association (now American College of Rheumatology); IHC, immunohistochemistry; FI, flow cytometry/intracellular staining; FS, flow cytometry/surface staining; NSAIDs, non-steroidal anti-inflammatory drugs; MTX, Methotrexate; SSZ, sulfasalazine. 


\begin{tabular}{|c|c|c|c|c|c|c|c|}
\hline $\begin{array}{l}\text { Antibodies } \\
\text { (clone) }\end{array}$ & $\begin{array}{l}\text { Antigen } \\
\text { recognised }\end{array}$ & $\begin{array}{l}\text { Cellular } \\
\text { localisation }\end{array}$ & Main cellular expression & $\begin{array}{l}\text { Concentration } \\
(\mu \mathrm{g} / \mathrm{ml})\end{array}$ & Assay & Source & Location \\
\hline $\begin{array}{l}\lg G 1 \\
\lg G 2 a\end{array}$ & $\begin{array}{l}\text { Isotype control } \\
\text { Isotype control }\end{array}$ & & $\begin{array}{l}\text { (lgG1 isotype control) } \\
\text { (lgG2a isotype control) }\end{array}$ & $\begin{array}{l}10 \\
10\end{array}$ & $\begin{array}{l}\mathrm{F} / \mathrm{IHC} \\
\mathrm{F} / \mathrm{IHC}\end{array}$ & $\begin{array}{l}\text { Dako } \\
\text { Dako }\end{array}$ & $\begin{array}{l}\text { Hamburg, Germany } \\
\text { Hamburg, Germany }\end{array}$ \\
\hline AS02 & CD90 & Membrane & $\begin{array}{l}\text { Fibroblasts, endothelial cells, } \\
\text { thymocytes }\end{array}$ & 10 & $\mathrm{~F} / \mathrm{IHC}$ & Dianova & Hamburg, Germany \\
\hline TÜK4 & CD14 & Membrane & Monocyłes/macrophages & 10 & $\mathrm{~F}$ & Dako & Hamburg, Germany \\
\hline CLB-mon/1 & CD14 & Membrane & Monocytes/macrophages & 10 & $\mathrm{IHC}$ & $\begin{array}{l}\text { Research } \\
\text { Diagnostics Inc }\end{array}$ & Flanders, USA \\
\hline TM316 & CD11b & Membrane & $\begin{array}{l}\text { Monocytes/macrophages, } \\
\text { PMN, NK cells }\end{array}$ & 10 & $\mathrm{~F}$ & Dianova & Hamburg, Germany \\
\hline $3-2 \mathrm{~B} 12$ & $\begin{array}{l}\text { Prolyl 4- } \\
\text { hdroxylase }\end{array}$ & Cytoplasm & Fibroblasts, endothelial cells & 10 & $\mathrm{~F} / \mathrm{IHC}$ & Dianova & Hamburg, Germany \\
\hline KP1 & CD68 & & Monocytes/macrophages & 10 & $\mathrm{~F} / \mathrm{IHC}$ & Dako & Hamburg, Germany \\
\hline EBM11 & CD68 & & Monocyłes/macrophages & 43 & $\mathrm{~F} / \mathrm{IHC}$ & Dako & Hamburg, Germany \\
\hline PGM1 & CD68 & & Monocyłes/macrophages & 36 & $\mathrm{~F} / \mathrm{IHC}$ & Dako & Hamburg, Germany \\
\hline
\end{tabular}

diaminobenzidine peroxidase substrate tablet set (Sigma, Deisenhofen, Germany).

For double labelling after completion of single staining, sections were first incubated with $20 \%$ human serum/PBS for 20 minutes. Then the specific antibodies, diluted in PBS/10\% horse serum, were added for 45 minutes. For detection, sections were incubated for 45 minutes with an alkaline phosphatase coupled goat antimouse antibody (Dako, Hamburg, Germany). The alkaline phosphatase was disclosed using a solution containing FAST Blue BB $(1.0 \mathrm{mg} / \mathrm{ml})$, and naphthol AS-MX phosphate $(0.3 \mathrm{mg} / \mathrm{ml}$; Sigma) in $0.2 \mathrm{M}$ Tris- $\mathrm{HCl}$, pH 8.4. Endogenous alkaline phosphatase was blocked with $0.24 \mathrm{mg} / \mathrm{ml}$ levamisole (Sigma). For isotype controls, no positive staining was seen in single staining or double labelling experiments.

\section{Evaluation of tissue sections after immunohistochemistry}

The percentage of positively stained cells was scored semiquantitatively by two observers (EK, RWK) in a "blinded" manner. Single-positive cells were identified by unequivocal brown (peroxidase) or blue (alkaline phosphatase) staining, whereas double-positive cells showed a mixture of both colours (dirty brown-blue colour).

\section{Tissue digestion and cell culture}

Synovial cells were obtained as previously published. ${ }^{21}$ Briefly, SFB were isolated by trypsin/collagenase digestion (Roche, Mannheim, Germany), short term in vitro adherence (7 days) to remove non-adherent cells, and negative isolation using magnetobead coupled anti-CD14 mAbs (Dynal, Hamburg, Germany). This procedure resulted in high enrichment of SFB with a contamination of $<2 \%$ leucocytes or endothelial cells.

\section{Isolation of skin fibroblasts}

Primary-culture skin FB were prepared as published previously. ${ }^{21}$

\section{Isolation of gingival fibroblasts}

Samples of gingival tissue were obtained during removal of granulation tissue from chronically inflamed dental roots. Gingival tissue samples were finely minced with scissors and digested for 30 minutes at $37^{\circ} \mathrm{C}$ in $10 \mathrm{ml}$ PBS containing $0.25 \%$ trypsin (Gibco). After trypsin treatment, tissue samples were digested in $10 \mathrm{ml} 0.1 \%$ collagenase $\mathrm{P}$ (Boehringer Mannheim) in Dulbecco's modified Eagle's medium (DMEM; Gibco)/10\% fetal calf serum (FCS; Gibco) for 2 hours at $37^{\circ} \mathrm{C}$. The tissue was dispersed by repeated pipetting and the cells were collected by centrifugation and washed with serum-free DMEM. Thereafter, the cells were cultured in DMEM/10\% FCS, $12.5 \mathrm{mM}$ HEPES, penicillin ( $100 \mathrm{U} / \mathrm{ml})$, streptomycin $(100 \mu \mathrm{g} / \mathrm{ml})$, and amphotericin B (2.5 mg/ml; all Gibco). The medium was changed every 2-3 days.

\section{THP- 1 and U937 cell lines}

The human monocytic cell lines THP-1 and U937 (both from the German collection of micro-organisms and cell cultures (DMSZ), Braunschweig, Germany) were grown in suspension culture in RPMI 1640 medium containing 10\% FCS (both Gibco) without antibiotics.

\section{Flow cytometry}

FACS analysis of negatively purified RA SFB, OA SFB, and skin FB was performed to characterise their purity and their CD68 expression. Table 2 indicates the concentrations of mAbs used. For immunofluorescence labelling, $2 \times 10^{5}$ cells were suspended in $100 \mu \mathrm{l} \mathrm{PBS} / 1 \% \mathrm{FCS} / 0.02 \% \mathrm{NaN}_{3}$. The cells were incubated with unconjugated primary mAbs, followed by incubation with FITC labelled secondary mAb (each for 30 minutes at $4^{\circ} \mathrm{C}$ ). After every step, cells were washed three times with $\mathrm{PBS} / 1 \% \mathrm{FCS} / 0.02 \% \mathrm{NaN}_{3}$. Specificity of staining was confirmed using equal concentrations of isotype matched control mAbs.

For intracellular staining, cells were washed twice with $\mathrm{PBS} / 1 \% \mathrm{FCS} / 0.02 \% \mathrm{NaN}_{3}$ and fixed for 10 minutes at $4{ }^{\circ} \mathrm{C}$ in 4\% PFA (Fluka, Deisenhofen, Germany). After washing twice with $\mathrm{PBS} / 1 \% \mathrm{FCS} / 0.02 \% \mathrm{NaN}_{3}$, the pellet was resuspended in permeabilisation buffer (PBS/1\% FCS $/ 0.02 \% \mathrm{NaN}_{3}$, and $0.5 \%$ saponin; Serva, Heidelberg, Germany) and incubated for 10 minutes at RT. Unlabelled primary mAbs were added at saturating concentrations and detected with a secondary FITC labelled goat antimouse antibody (Dako), both for 45 minutes at $4^{\circ} \mathrm{C}$ in permeabilisation buffer.

Analyses were performed on a FACS-Calibur using the software Cell Quest (Becton Dickinson, San Jose, CA, USA). Forward and side scatter gates were set to include all viable cells. A gate was set to exclude $99 \%$ of the cells stained with control immunoglobulins. To determine the percentage of THP-1 and U937 cells positive for CD68 (surface and intracellular staining), a gate was placed at the intercept of the curves obtained with specific mAbs and control immunoglobulins; the percentage of cells stained with control 
immunoglobulin was then subtracted from the percentage of cells stained with the specific mAb.

\section{Statistical analysis}

The non-parametric Mann-Whitney U test was applied for data analyses using the software SPSS 10.0 (SPSS Inc; Chicago, IL, USA). Significant differences were accepted for $\mathrm{p} \leqslant 0.05$.

\section{RESULTS}

\section{Immunohistochemistry}

Although CD68 is commonly used as a specific marker for $\mathrm{M} \phi$, CD68 is also expressed in cell types not originating from the monocytic/M $\phi$ lineage. To characterise the specificity of three widely used anti-CD68 mAbs (KPl, EBMll, and PGMl) for $M \phi$ in SM, expression of the different CD68 epitopes was compared with the distribution of the FB markers CD90 and prolyl 4-hydroxylase, as well as the monocyte/M $\phi$ marker CDI4.

\section{RA synovial membranes}

In the lining layer, between $67 \%$ and $62 \%$ of the cells were positive for the FB markers prolyl 4-hydroxylase or CD90 and $83 \%$ positive for the monocyte/M $\phi$ marker CDI4 (figs $1 \mathrm{E}$ and I; table 3). The anti-CD68 mAbs KPl and EBMll stained almost all cells, whereas the anti-CD68 mAb PGMl detected only $3 \%$ (table 3 ).

In diffuse infiltrates, about $50 \%$ of the cells stained positively for the FB markers prolyl 4-hydroxylase or CD90 and $68 \%$ positively for the monocyte/M $\phi$ marker $\mathrm{CD} 14$. The anti-CD68 mAbs KPl and EBM11 stained about $75 \%$ of the cells, whereas the anti-CD68 mAb PGMl detected only 17\% of the cells (table 3).

In lymphoid aggregates, $70 \%$ and $10 \%$ of the cells showed a positive reaction for the FB markers prolyl 4-hydroxylase and CD90, respectively, and $8 \%$ for the monocyte/ $\mathrm{M} \phi$ marker CD14. The anti-CD68 mAbs KPl and EBMll detected between $20 \%$ and $25 \%$ of the cells, the anti-CD68 mAb PGMI 5\% of the cells (table 3 ).

In the stroma, about $90 \%$ of the cells were positive for the FB markers prolyl 4-hydroxylase and CD90 and 37\% were positive for the monocyte/M $\phi$ marker CD14. The anti-CD68 mAbs KPl and EBMIl detected about $80 \%$, and the antiCD68 mAb PGM1 10\% of the cells (table 3).

All endothelial cells were stained by the anti-CD90 mAb AS02 and the anti-CD68 mAb KPl. About 50\% of the endothelial cells stained positively for prolyl 4-hydroxylase. Neither the anti-CDl4 mAb nor the CD68 mAbs EBMll or PGMI detected any endothelial cells.

\section{OA synovial membranes}

The expression of the three different CD68 epitopes, the FB marker CD90, and the monocyte/M $\phi$ marker CD14 in the OA SM was comparable to that seen in the RA SM, with the exception of the lining layer.

In the lining layer of the OA SM, about $2 \%$ of the cells were positive for the FB marker CD90 and $83 \%$ for the monocyte/ $\mathrm{M} \phi$ marker CD14. The anti-CD68 mAbs KPl and EBMll stained almost all cells, the anti-CD68 mAb PGMl only 17\% (table 3).

The percentage of $\mathrm{CD}^{+} 0^{+}$cells in the lining layer of the RA SM was significantly higher $(\mathrm{p} \leqslant 0.05)$ than that seen in the OA SM.

\section{Double staining using IHC}

Cells in the lining layer of the RA and OA SM were not double positive for CD90 and CD68/KPl or CD68/EBM11 (figs $\mathrm{IF}$ and $\mathrm{G}$ ). However, the strong blue staining for CD68 in the lining layer of the RA SM (figs $1 B-D, F-H$, and $J-L$ ) may have covered the weak brown staining for CD90 (fig IE) and therefore obscured double-positive cells (table 3). In diffuse infiltrates of the RA and OA SM, about $15-30 \%$ of the cells were double positive for AS02 and CD68/KP1 or CD68/ EBMI l, in the stroma of RA and OA synovial tissue between 0 and $16 \%$ of the cells (figs $\mathrm{IF}$ and G). In both RA and OA synovial tissue, nearly all endothelial cells stained double positive for CD90 and CD68/KPl (figs IE and F). There were no significant differences for any parameter or region between RA and OA synovial tissue.

\section{Flow cytometry}

To assess the specificity of the three anti-CD68 mAbs KPl, EBMIl, and PGMl for $\mathrm{M} \phi$ in FACS, expression of the different CD68 epitopes in monocytic cell lines and isolated $\mathrm{SFB}$, skin $\mathrm{FB}$, and gingival $\mathrm{FB}$ was compared with the expression of the FB markers CD90 and prolyl 4-hydroxylase, as well as the monocyte/M $\phi$ marker CD14. Because macrosialin, the murine homologue of CD68, is also expressed on the cell surface, both surface and intracellular staining were performed. Finally, the influence of the individual fixation steps used for intracellular staining on the detection of the different CD68 epitopes was assessed.

\section{CD1 4 and CD90 expression on the surface of THP- 1 and $U 937$ cells}

About $84 \%$ of unfixed THP-1 cells showed a positive surface staining for the monocyte/M $\phi$ marker CD14 and $21 \%$ for the FB marker CD90 (table 4). In unfixed U937 cells, about $88 \%$ were surface positive for the monocyte/M $\phi$ marker CD14 and $2 \%$ for CD90. The percentage of $\mathrm{CD}^{+} 0^{+} \mathrm{THP}-\mathrm{l}$ cells was significantly higher than that of $\mathrm{CD}^{+} 0^{+}$in $\mathrm{U} 937$ cells (table 4).

\section{CD68 expression in THP-1 and U937 cells \\ THP- 1 cells}

Upon surface staining of unfixed THP-1 cells, about 17\% were $\mathrm{CD} 8 / \mathrm{KPl}^{+}$(fig 2; table 4). The percentage of CD68/EBMII ${ }^{+}$ cells was significantly higher than the percentage of $\mathrm{KPI}^{+}$ cells, but the highest percentage of $\mathrm{CD}^{+} 8^{+}$cells was detected with the mAb PGMl ( $p \leqslant 0.05$ as compared with $\mathrm{CD} 68 / \mathrm{KPl}^{+}$ and $\mathrm{CD} 68 / \mathrm{EBMII}^{+}$cells; table 4 ).

After pre-fixation with $4.0 \%$ PFA, in contrast, decreasing percentages of the cells were $\mathrm{CD} 68 / \mathrm{KPl}^{+}, \mathrm{CD} 68 / \mathrm{EBMl} 1^{+}$, and $\mathrm{CD} 68 / \mathrm{PGMl}^{+}$(fig 2; table 4).

Upon intracellular staining, the anti-CD68 mAbs KPl and EBMll stained almost all cells $\left(\mathrm{CD} 68 / \mathrm{KPl}^{+}>\mathrm{CD} 68 / \mathrm{EBMll}^{+}\right)$, the mAb PGMl only $26 \%\left(\mathrm{CD} 68 / \mathrm{PGMI}^{+}<\mathrm{CD} 68 / \mathrm{KPl}^{+}\right.$or CD68/EBMII ${ }^{+} ; \mathrm{p} \leqslant 0.05$; fig 2, table 4).

\section{U937 cells}

Upon surface staining of unfixed U937 cells, about $10 \%$ of the cells were $\mathrm{CD} 68 / \mathrm{KPI}^{+}$(fig 2; table 4 ). The percentages of $\mathrm{CD} 8 / \mathrm{EBMII}^{+}$and $\mathrm{CD} 68 / \mathrm{PGMI}^{+}$cells were both significantly higher than those of $\mathrm{CD} 68 / \mathrm{KPI}^{+}$cells.

After pre-fixation with $4.0 \%$ PFA, in contrast, decreasing percentages of the cells were CD68/KPl ${ }^{+}, \mathrm{CD} 68 / \mathrm{EBMII}^{+}$, and CD68/PGMI ${ }^{+}$(fig 2, table 4).

Upon intracellular staining, the anti-CD68 mAbs KPl and EBMl 1 stained almost all cells $\left(\mathrm{CD} 68 / \mathrm{KPl}^{+}>\mathrm{CD} 68 / \mathrm{EBMl}^{+}\right)$, the mAb PGMl only $6.2 \%\left(\mathrm{CD} 68 / \mathrm{PGMI}^{+}<\mathrm{CD} 68 / \mathrm{KPl}^{+}\right.$or CD68/EBMII ${ }^{+} ; \mathrm{p} \leqslant 0.05$; fig 2, table 4).

For the KPl and the EBMll epitope, intracellular staining of both THP-1 and U937 cells resulted in significantly higher percentages of positive cells than surface staining of unfixed or pre-fixed cells (table 4). For the PGMI epitope, in contrast, the percentages of positive THP-1 and U937 upon surface staining of unfixed cells were significantly higher than upon surface staining of pre-fixed cells or intracellular staining. 

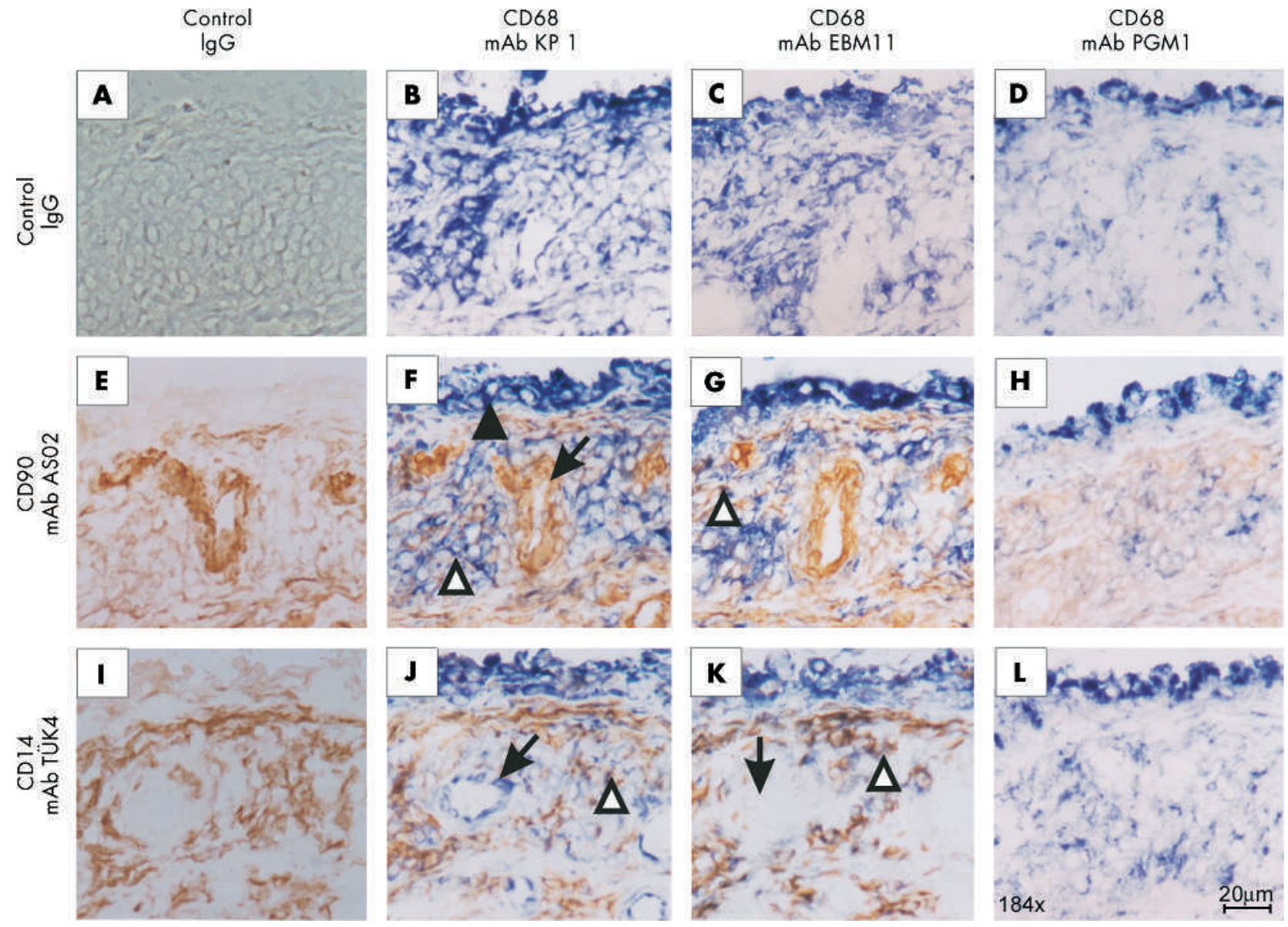

Figure 1 Immunohistochemical analysis of synovial tissue from one representative patient with RA for CD68 (mAbs KP1, EBM1 1, and PGM1), the FB marker CD90 (mAb AS02), and the monocyte/ M $\phi$ marker CD14 (mAb TÜK4). Control isotype matched mAbs showed no positive reaction (fig 1A). The anti-CD68 mAbs KPI (B) and EBM1 1 (C) strongly stained cells in the lining layer (filled arrowhead in fig 1F), diffuse infiltrates, and stroma. The $\mathrm{mAb} K P 1$ also detected endothelial cells (B; arrow in fig $1 \mathrm{~J})$. The anti-CD90 mAb ASO2 very faintly stained cells in the lining layer, whereas this mAb strongly stained endothelial cells ( $\mathrm{E}$; arrow in fig $\mathrm{TF}$ ). Cells in diffuse infiltrates and stroma were weakly stained by this $\mathrm{mAb}$. The anti-CD14 mAb TUK4 faintly stained cells in the lining layer (I). This mAb strongly stained cells in the diffuse infiltrates and the stroma. After double staining experiments with the anti-CD68 mAb KP1 or EBM1 1 (blue colour) and the anti-CD90 mAb ASO2 (brown colour), double-positive cells in diffuse infiltrates were seen ( $F$ and $\mathrm{G}$; open arrowheads figs $1 \mathrm{~F}$ and $\mathrm{G}$ ). After double staining experiments with the anti-CD68 KP1 or EBM1 1 (blue colour) and the anti-CDI4 mAb TüK4 (brown colour), double-positive cells in diffuse infiltrates were seen ( $\mathrm{J}$ and $\mathrm{K}$; open arrowheads in figs $1 \mathrm{~J}$ and $\mathrm{K}$ ). The anti-CD68 mAb PGM1 strongly stained cells in the lining layer and diffuse infiltrates $(D, H$, and $L)$. This strong staining was only seen after fixation of the tissue sections with PFA followed by heating in SSC.

\section{Intracellular/surface expression of prolyl 4- hydroxylase, CD90/Thy-1, CD14, and CD 116 in different fibroblasts}

In RA SFB, OA SFB, JT SFB, skin FB, and gingival FB, 93$100 \%$ of the cells were prolyl 4-hydroxylase ${ }^{+}$(fig 3; table 5). A numerically or significantly lower percentage of the cells were $\mathrm{CD}^{+} 0^{+}$. Less than or equal to $2.0 \%$ of the cells were $\mathrm{CD} 14^{+}$and $\mathrm{CD} \mathrm{lb}^{+}$. Table 5 also shows the cultivation times.

No significant differences were seen between SFB from patients with RA and OA. However, JT SFB significantly differed from RA SFB and OA SFB for some parameters (table 5).

In skin $\mathrm{FB}$ and gingival $\mathrm{FB}$, the percentage of $\mathrm{CD} 14^{+}$cells was significantly higher than that of $\mathrm{CDI} \mathrm{lb}^{+}$cells (see table 5 for comparisons with SFB).

Intracellular expression of CD68 in different fibroblasts

\section{Synovial fibroblasts}

In RA SFB approximately $95 \%$ of the cells were $\mathrm{CD} 68 / \mathrm{KPI}^{+}$or $\mathrm{CD}$ 68/EBMII ${ }^{+}$(fig 3; table 6). However, the percentage of CD68/PGMI ${ }^{+}$cells was significantly lower than that of CD68/ $\mathrm{KPl}^{+}$and $\mathrm{CD} 68 / \mathrm{EBMll}^{+}$cells (table 6).
In OA SFB almost all cells were $\mathrm{CD} 68 / \mathrm{KPI}^{+}$and $\mathrm{CD} 68 /$ $\mathrm{EBMII}^{+}$(fig 3; table 6). However, as in RA SFB, the percentage of $\mathrm{CD} 68 / \mathrm{PGMI}^{+}$cells was significantly lower than the percentages of $\mathrm{CD} 68 / \mathrm{KPl}^{+}$and $\mathrm{CD} 68 / \mathrm{EBMII}^{+}$cells (table 6).

In JT SFB almost all cells were $\mathrm{CD} 68 / \mathrm{KPl}^{+}$and $\mathrm{CD} 68$ / $\mathrm{EBMII}^{+}$(fig 3; table 6). As in RA SFB and OA SFB, a significantly lower percentage of the cells were CD68/PGMI ${ }^{+}$ (table 6).

\section{Skin fibroblasts}

To characterise CD68 expression in skin FB, cells from healthy subjects $(n=3)$, patients with RA $(n=4)$, and patients with OA $(n=5)$ were analysed by FACS. Figure 3 shows representative results of $\mathrm{OA}$ skin $\mathrm{FB}$ - that is, intracellular staining for prolyl 4-hydroxylase and CD68 or surface staining for CD90 as a FB marker. No significant differences were seen for any marker when the percentages of positive cells from the three different FB populations were compared (data not shown). Therefore, the results were pooled (table 6).

In skin $\mathrm{FB}$, about $97 \%$ of the cells were $\mathrm{CD} 68 / \mathrm{KPl}^{+}$and $\mathrm{CD} 8 / \mathrm{EBMIl}^{+}$. As in SFB, the percentage of $\mathrm{CD} 68 / \mathrm{PGMI}^{+}$ 
Table 3 Percentages of $\mathrm{CD} 90^{+}, \mathrm{CD} 14^{+}, \mathrm{CD} 68 / \mathrm{KPI}^{+}, \mathrm{CD} 68 / \mathrm{EBM1} 1^{+}$, and $\mathrm{CD} 68 / \mathrm{PGM1}{ }^{+}$cells in different histological areas of the synovial membrane (SM) of patients with RA and $O A$ ( $n=3$ each; $n=2$ and $n=1$ for lymphoid aggregates in the RA and OA SM, respectively)

\begin{tabular}{|c|c|c|c|c|c|c|}
\hline & $\mathrm{mAb}$ & Lining layer & Diffuse infiltrates & Lymphoid aggregates & Stroma & Endothelial cells \\
\hline \multicolumn{7}{|c|}{ Rheumatoid arthritis } \\
\hline $\mathrm{P} 4 \mathrm{H}$ & $3-2 B 12$ & $66.7(18.6)$ & $53.3(3.3)$ & 70.0 & $90.0(10.0)$ & $50.0(5.8)$ \\
\hline CD90 & $\mathrm{ASO} 2$ & $61.8(26.8)^{*}$ & $50.0(11.6)$ & $10.0(0.0)$ & $86.9(6.7)$ & $100.0(0.0)$ \\
\hline \multicolumn{7}{|c|}{ Macrophages } \\
\hline CD14 & CLB & $83.3(8.8)$ & $68.3(13.6)$ & $7.5(2.5)$ & 36.7 (13.3) & $0.0(0.0)$ \\
\hline CD68 & KPI & $96.7(3.3)$ & 75.0 (13.2) & $25.0(5.0)$ & $83.3(6.0)$ & $100.0(0.0)$ \\
\hline CD68 & EBM11 & $96.7(3.3)$ & 75.0 (13.3) & $20.0(0.0)$ & 78.3 (10.1) & $0.0(0.0)$ \\
\hline CD68 & PGM1 & $3.3(3.3)$ & 16.7 (12.0) & $5.0(5.0)$ & $10.0(2.9)$ & $0.0(0.0)$ \\
\hline \multicolumn{7}{|c|}{ Osteoarthritis } \\
\hline CD90 & ASO2 & $1.7(1.7)$ & $36.7(23.3)$ & 10.0 & $60.0(17.3)$ & $96.7(3.3)$ \\
\hline \multicolumn{7}{|c|}{ Macrophages } \\
\hline CD14 & $C L B$ & $83.3(6.7)$ & $53.3(3.3)$ & 10.00 & 36.7 (14.5) & $0.0(0.0)$ \\
\hline CD68 & KP1 & $96.7(3.3)$ & $73.3(12.0)$ & 10.00 & $70.0(10.0)$ & $90.0(5.8)$ \\
\hline CD68 & EBM11 & $96.7(3.3)$ & 66.7 (14.5) & 10.00 & $53.3(6.7)$ & $0.0(0.0)$ \\
\hline CD68 & PGM1 & $16.7(12.0)$ & $13.3(3.3)$ & 0.0 & 6.7 (3.3) & $0.0(0.0)$ \\
\hline
\end{tabular}

${ }^{*} \mathrm{p} \leqslant 0.05$ Mann-Whitney $\mathrm{U}$ test versus $\mathrm{OA}$.

$\mathrm{P} 4 \mathrm{H}$, prolyl 4-hydroxylase.

Data are expressed as means (SEM).

cells was significantly lower than the percentages of CD68/ $\mathrm{KPl}^{+}$or $\mathrm{CD} 68 / \mathrm{EBMII}^{+}$cells (fig 3; table 6). The PGMl expression was also significantly lower than the CD90 expression (see table 6 for comparisons with SFB).

\section{Gingival fibroblasts}

Almost all cells were $\mathrm{CD} 68 / \mathrm{KPI}^{+}$; a significantly lower percentage $\mathrm{CD} 68 / \mathrm{EBMII}^{+}$(fig 3; table 6 ). The percentage of $\mathrm{CD} 68 / \mathrm{PGMl}^{+}$cells was significantly lower than the percentages of $\mathrm{CD} 68 / \mathrm{KPl}^{+}$or $\mathrm{CD} 68 / \mathrm{EBMII}^{+}$gingival $\mathrm{FB}$ (see table 6 for comparisons with SFB).

Surface expression of CD68 in different fibroblasts Synovial fibroblasts

In RA SFB about $5 \%$ of the cells were CD68/KP1 ${ }^{+}$and CD68/ $\mathrm{EBMII}^{+}$(fig 4; table 7), and a significantly lower percentage CD68/PGMI ${ }^{+}$. The percentages of $\mathrm{CD} 68 / \mathrm{KPl}^{+}$and $\mathrm{CD} 68 /$

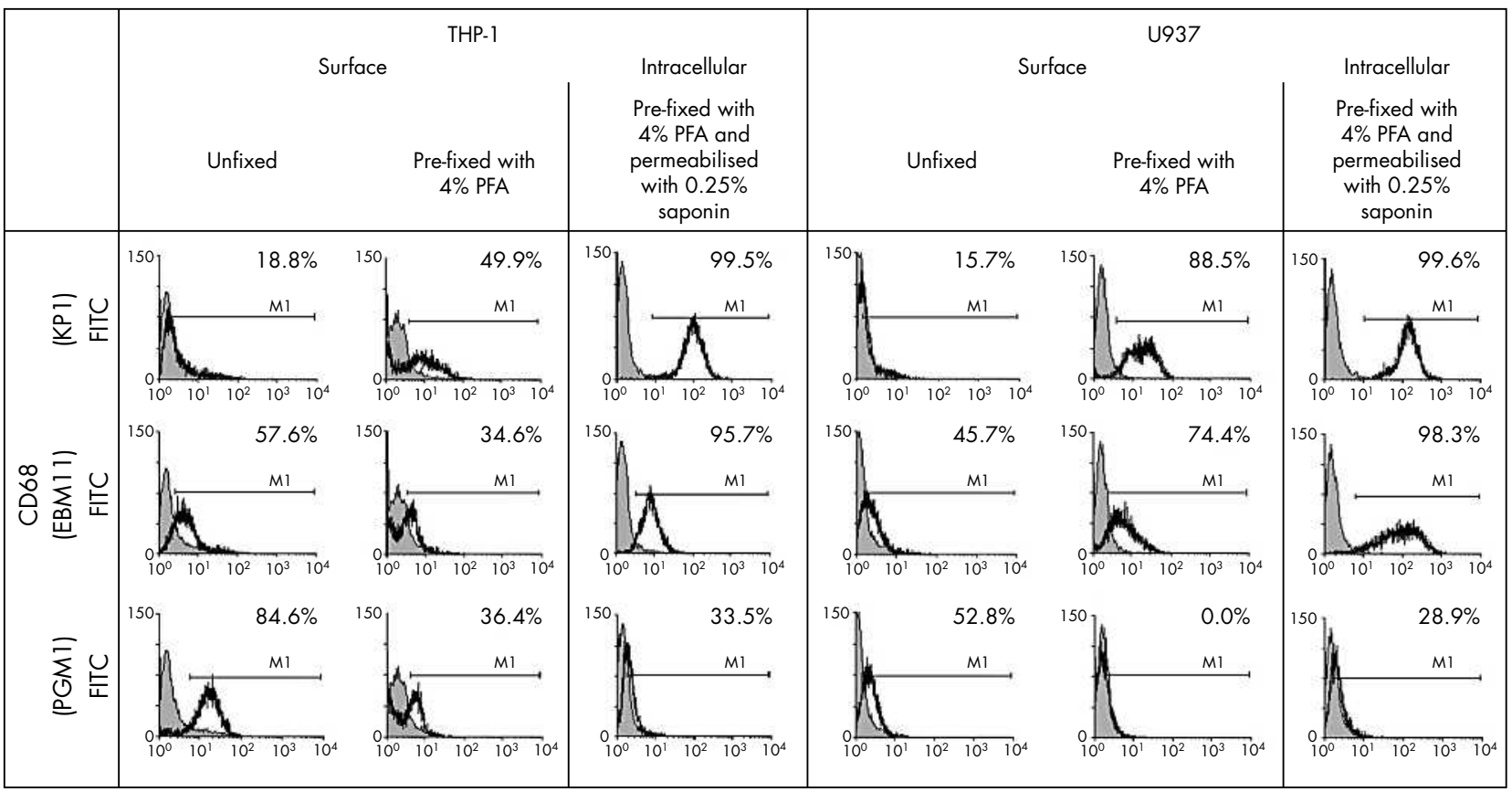

Figure 2 Flow cytometry analysis of the human monocytic cell lines THP-1 and U937 for CD68 (mAbs KP1, EBM1 1, and PGM1) using unfixed cells, cells after pre-fixation with $4 \%$ PFA, or cells after pre-fixation and permeabilisation with $0.25 \%$ saponin (in each case, data from one representative experiment are shown). In both cell lines, the percentages of positive cells for the anti-CD68 mAbs KP1 and EBM1 1 increased from surface staining of unfixed cells over surface staining of pre-fixed cells to intracellular staining of pre-fixed and permeabilised cells. In contrast, the percentages of positive cells for the anti-CD68 mAb PGM1 was highest on unfixed cells and decreased after pre-fixation with PFA or after pre-fixation with PFA and permeabilisation with saponin (isotype control: shaded curve; specific antibodies: black line). 
Table 4 Percentage of CD68 positive THP-1 cells $(n=5)$ and U937 cells $(n=6)$ after surface staining of unfixed cells, surface staining of cells pre-fixed with $4.0 \%$ PFA, or intracellular staining of cells fixed with $4.0 \%$ PFA and permeabilised with $0.25 \%$ saponin

\begin{tabular}{|c|c|c|c|c|c|c|c|}
\hline & \multirow[b]{3}{*}{$(\mathrm{mAb})$} & \multicolumn{3}{|l|}{ THP-1 } & \multicolumn{3}{|l|}{ U937 } \\
\hline & & \multicolumn{2}{|l|}{ Surface staining } & \multirow{2}{*}{$\begin{array}{l}\text { Intracellular staining } \\
\text { Pre-fixed with } 4.0 \% \text { PFA } \\
\text { and permeabilised with } \\
0.25 \% \text { saponin }\end{array}$} & \multicolumn{2}{|l|}{ Surface staining } & \multirow{2}{*}{$\begin{array}{l}\text { Intracellular staining } \\
\text { Pre-fixed with } 4.0 \% \text { PFA } \\
\text { and permeabilised with } \\
0.25 \% \text { saponin }\end{array}$} \\
\hline & & Unfixed cells & $\begin{array}{l}\text { Pre-fixed with } \\
4.0 \% \text { PFA }\end{array}$ & & Unfixed cells & $\begin{array}{l}\text { Pre-fixed with } \\
4.0 \% \text { PFA }\end{array}$ & \\
\hline CD14 & TÜK4 & & & \\
\hline CD90 & ASO2 & \multicolumn{3}{|l|}{$21.2(4.6)(n=3)$} & & $2.3(1.5)^{-}(n=4)$ & \\
\hline CD68 & KPI & $17.3(0.8)$ & $61.0(7.0)^{*}$ & $98.3(0.5)^{\star} \dagger$ & $10.0(3.2)$ & $76.5(12.1)^{*}$ & $99.2(0.2)^{*} \dagger$ \\
\hline CD68 & EBM11 & $43.6(5.4) \ddagger$ & $41.0(6.4)$ & $95.1(1.0)^{*} \dagger \ddagger$ & $57.9(5.1) \ddagger$ & $71.7(5.5)^{\top}$ & $97.1(1.1)^{\star} \dagger \ddagger$ \\
\hline CD68 & PGMI & 80.1 (3.2)‡§ & $36.7(9.3)^{*}$ & $25.5(3.0)^{*} \neq \S$ & $57.8(3.9) \neq$ & $19.3(7.4)^{\star} \ddagger \S$ & $6.2(4.7)^{*} \neq 5$ \\
\hline \multicolumn{8}{|c|}{$\begin{array}{l}m A b \text {, monoclonal antibody; PFA, paraformaldehyde } \\
{ }^{*} p \leqslant 0.05 \text { Mann-Whitney } U \text { test versus surface staining of unfixed cells. } \\
t p \leqslant 0.05 \text { versus surface staining of surface staining of pre-fixed cells. } \\
\pm p \leqslant 0.05 \text { Mann-Whitney } U \text { test versus CD } 68, K P 1 . \\
\$ p \leqslant 0.05 \text { Mann-Whitney } U \text { test versus CD68, EBM } 11 \\
\mp p \leqslant 0.05 \text { Mann-Whitney } U \text { test versus THP-1. } \\
\text { Data are expressed as means (SEM). }\end{array}$} \\
\hline
\end{tabular}

$\mathrm{EBMI}^{+}$cells were significantly higher than those of $\mathrm{CD}^{+} 4^{+}$ cells (table 7).

In $\mathrm{OA} \mathrm{SFB}$ about $6-8 \%$ of the cells were $\mathrm{CD} 68 / \mathrm{KPI}^{+}$or $\mathrm{CD}$ 68/EBMII ${ }^{+}$(fig 4; table 7), and a significantly lower percentage were $\mathrm{CD} 68 / \mathrm{PGMI}^{+}$. The percentages of positive cells for all three tested anti-CD68 mAb cells were significantly higher than those of $\mathrm{CD} 14^{+}$cells (table 7).

\section{Skin fibroblasts}

Less than $1.5 \%$ of the cells were $\mathrm{CD} 68 / \mathrm{KPl}^{+}$or $\mathrm{CD} 68 / \mathrm{EBMIl}^{+}$ (fig 4; table 7); a significantly lower percentage were CD68/ $\mathrm{PGMI}^{+}$. As compared with the percentages of $\mathrm{CDl} 4^{+}$cells, only the percentages of $\mathrm{CD}^{+} 8^{+} / \mathrm{PGMI}^{+}$cells were significantly lower (see table 7 for significant differences in comparison with SFB).

\section{Gingival fibroblasts}

About $2 \%$ of the cells were $\mathrm{CD} 68 / \mathrm{KPI}^{+}$or $\mathrm{CD} 68 / \mathrm{EBMII}^{+}$ (fig 4; table 7), and a significantly lower percentage CD68/ $\mathrm{PGMI}^{+}$. As compared with the percentages of $\mathrm{CD} 14^{+}$cells, only the percentages of $\mathrm{CD} 68 / \mathrm{PGMI}^{+}$cells were significantly lower (see table 7 for significant differences in comparison with SFB).

\section{DISCUSSION \\ Overlap between positivity for monocyte $/ M \phi$ and fibroblast markers in synovial tissue}

In the lining layer of the RA and OA SM, nearly all cells stained positively by IHC for the CD68 mAbs KPl and EBM11. About $83 \%$ of the lining layer cells were unequivocally identified as monocytes/M $\phi$ by positivity for CDI4. However, about $65 \%$ of the lining layer cells were also positive for the FB markers CD90/prolyl 4-hydroxylase. Therefore at least $45 \%(\max 65 \%$ ) of the cells in the lining layer of the RA SM were positive for both $\mathrm{M} \phi$ and FB markers. A similar overlap between the staining for the CD68 epitopes recognised by the mAbs KPl and EBMll and staining for $\mathrm{M} \phi$ markers and FB markers was also seen in diffuse infiltrates of the RA SM, in which at least 18\% (max $25 \%$ ) of the cells were positive for both $\mathrm{M} \phi$ markers and FB markers, and in the stroma of the RA SM (overlap at least $24 \%$ and $\max 73 \%$ ). This overlap was confirmed by direct double staining IHC, showing up to $30 \%$ of cells double positive for $\mathrm{M} \phi$ and $\mathrm{FB}$ markers in different regions of the RA or OA SM. These results indicate that either the anti-CD68 mAbs KPI and EBMII did not exclusively recognise synovial $\mathrm{M} \phi$, but also SFB, or that synovial $\mathrm{M} \phi$ (in particular, in the lining layer) expressed markers usually restricted to FB. Indeed, certain CD68 epitopes (as detected, for example, by the mAbs Ki-M6 and Ki-M7) have been previously seen in cells with FB-like morphology in bone marrow cultures ${ }^{19}$ and in the stroma of the RA SM, ${ }^{22}$ indicating that SFB may express CD68. However, the present study represents, as far as we know, the first published report comparing the expression of the above markers systematically and demonstrating considerable overlap of $\mathrm{M} \phi$ and FB markers.

\section{Positivity of monocytic cell lines for monocyte $/ M \phi$ and fibroblast markers}

As a positive control for FACS analysis, the monocytic leukaemia cell lines THP-1 and U937 were analysed for the expression of monocyte/M $\phi$ and FB markers. In both cell lines, between $84 \%$ and $88 \%$ of the cells were surface positive for the monocyte/M $\phi$ marker CDI4, confirming their derivation from the monocyte/M $\phi$ cell lineage. This was further underlined by the positivity of these two monocytic cell lines for the $\mathrm{M} \phi$ marker CD68 (both about 100\% upon intracellular staining). However, in particular, U937 cells also showed surface positivity for CD90 (Thy-1), a marker normally restricted to FB and activated endothelial cells. ${ }^{21}$ This surprising, previously unreported finding indicates that the immature monocytic cell lines THP-1 and U937 may express $\mathrm{FB} /$ endothelial markers. It remains to be determined whether the expression of FB markers reflects the immature, possibly de-differentiated character of these cell lines or whether cells from completely different cell lineages may share common markers.

Interestingly, positivity of THP-1 and U937 cells for CD68 depended on both the mAb used for detection of CD68 and the fixation procedure applied. The percentage of positive cells was increased by pre-fixation with PFA and/or permeabilisation with saponin for the mAbs KPl and EBM11, whereas these pre-fixations decreased positivity for the mAb PGMI. In addition, the mAb PGMl only detected 85\% THP-1 and 53\% U937 cells. These technical considerations indicate that the suitability of monocytic cell lines as positive $\mathrm{M} \phi$ controls largely depends on the pretreatment and the mAb used. Also, this restricts the universal use of CD68 as a $\mathrm{M} \phi$ marker in both FACS analysis and immunohistochemistry (see fig 1 ).

The increase of $\mathrm{CD} 68 / \mathrm{KPl}^{+}$and $\mathrm{CD} 68 / \mathrm{EBMll}^{+}$cells upon fixation has been reported before for THP-1 and U937 cells ${ }^{14}$ and also for alveolar $\mathrm{M} \phi .{ }^{13}$ However, no other report has investigated the influence of fixation and fixation followed 


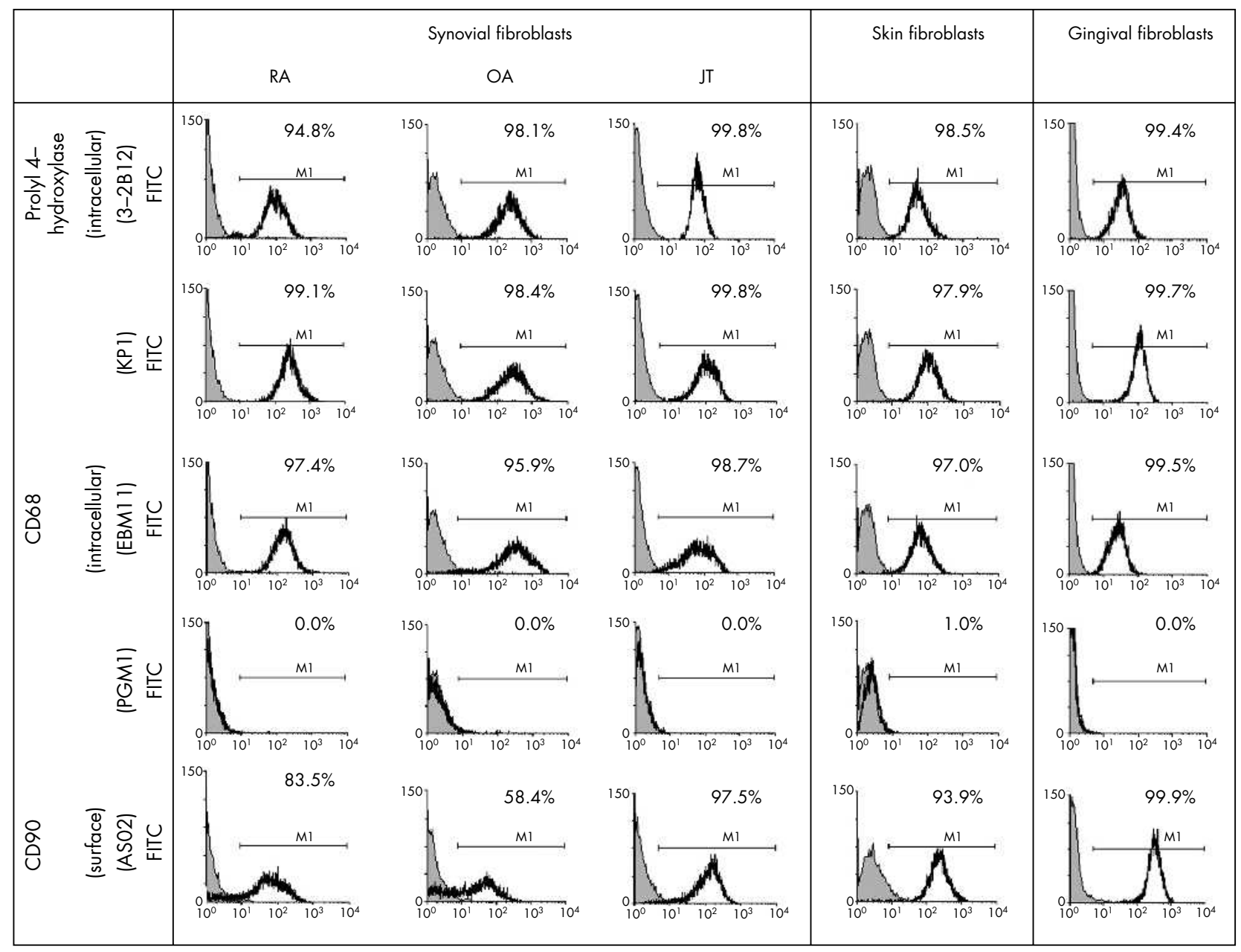

Figure 3 Flow cytometry analysis of RA SFB, OA SFB, and JT SFB, skin FB, and gingival FB for intracellular expression of prolyl 4-hydroxylase or CD68 (mAbs KPI, EBM1 1, and PGM1) and surface expression of the fibroblast marker CD90 (in each case, data from one representative experiment are shown). The anti-CD68 mAbs KPI and EBM1 1 showed a positive intracellular staining in a high percentage of SFB (RA, OA, and JT), skin FB, and gingival FB. In contrast, the anti-CD68 mAb PGM1 detected almost no cells in any of the FB populations. In all FB populations, nearly all cells stained positively for the FB marker prolyl 4-hydroxylase, whereas the percentage of positive cells for the FB marker CD90 varied depending on the FB population (isotype control: shaded curve; specific antibodies: black line).

by permeabilisation on the staining behaviour of the antiCD68 mAb PGMl. In contrast with the anti-CD68 mAbs KPl and EBMIl, the percentage of PGMI positive cells decreased depending on the pretreatment of the cells. Only Falini et al have used the antibody PGMI for surface staining of unfixed alveolar $\mathrm{M} \phi$ in flow cytometry analysis. ${ }^{23}$ However, in contrast with the positive staining of THP-1 and U937 seen in the present study, they noted no positive alveolar $\mathrm{M} \phi$.

\section{Expression of the $\mathrm{M} \phi$ marker CD68 in fibroblasts}

Limited suitability of $\mathrm{CD} 68$ as a $\mathrm{M} \phi$ marker is further underlined by the positivity of highly purified $(<2 \%$

Table 5 Percentages of synovial, skin, and gingival FB showing a positive surface/intracellular reaction for prolyl 4hydroxylase, CD90/Thy-1, CD14, or CD1 1b

\begin{tabular}{|c|c|c|c|c|c|c|}
\hline & \multirow[b]{2}{*}{$\mathrm{mAb}$} & \multicolumn{3}{|l|}{ Synovial FB } & \multirow{2}{*}{$\begin{array}{l}\text { Skin FB } \\
(n=12)\end{array}$} & \multirow{2}{*}{$\begin{array}{l}\text { Gingival FB } \\
(\mathrm{n}=9)\end{array}$} \\
\hline & & RA $(n=7)$ & $O A(n=9)$ & $J T(n=6)$ & & \\
\hline Prolyl 4-hydroxylase (intracellular) & $3-2 B 12$ & $92.9(2.0)$ & $96.8(1.0)$ & $99.6(0.2)^{*} \dagger$ & $97.6(0.5) \dagger \ddagger$ & $99.7(0.1)^{*}+\S$ \\
\hline CD90/Thy-1 (surface) & ASO2 & $65.0(7.5)^{\bullet}$ & $70.8(8.5)^{\top}$ & $93.6(2.7)^{*}+\odot(n=5)$ & $96.3(1.1)^{*}+$ & $99.7(0.1)^{*}+\ddagger \S$ \\
\hline CD14 (surface) & TÜK4 & $1.2(0.3)$ & $0.9(0.1)$ & $1.0(0.1)$ & $1.8(0.3)^{*}$ & $2.0(0.6)^{*} \ddagger$ \\
\hline CDI $1 \mathrm{~b}$ (surface) & TM316 & $2.0(0.5)$ & $1.3(0.2)(n=8)$ & $0.9(0.1)+(n=5)$ & $0.7(0.2)^{*} 十^{* *}(n=10)$ & $0.9(0.1) \dagger^{* *}$ \\
\hline In vitro culture (days) & & $7.0(0.0)$ & $10.7(2.5)$ & $28.0(5.4)^{*}+$ & $36.7(2.4)^{*}+\ddagger$ & $18.1(1.1)^{\star} \S$ \\
\hline
\end{tabular}

$\mathrm{mAb}$, monoclonal antibody; $\mathrm{FB}$, fibroblasts; $\mathrm{RA}$, rheumatoid arthritis; $\mathrm{OA}$, osteoarthritis; JT, joint trauma.

${ }^{*} p \leqslant 0.05$ Mann-Whitney U test versus OA SFB.

$t p \leqslant 0.05$ Mann-Whitney $U$ test versus RA SFB.

$\neq p \leqslant 0.05$ Mann-Whitney $U$ test versus JT SFBs.

$\S p \leqslant 0.05$ Mann-Whitney $U$ test versus skin FB.

T $p \leqslant 0.05$ Mann-Whitney U test versus prolyl 4-hydroxylase.

${ }^{* *} p \leqslant 0.05$ Mann-Whitney $U$ test versus CD14.

Data are expressed as means (SEM). 
Table 6 Percentage of CD68 positive SFB, skin FB, and gingival FB after intracellular staining of cells fixed with $4.0 \%$ PFA and permeabilisation with $0.25 \%$ saponin

\begin{tabular}{|c|c|c|c|c|c|c|}
\hline & \multirow[b]{2}{*}{$\mathrm{mAb}$} & \multicolumn{3}{|l|}{ Synovial fibroblasts } & \multirow{2}{*}{$\begin{array}{l}\text { Skin fibroblasts } \\
(n=12)\end{array}$} & \multirow{2}{*}{$\begin{array}{l}\text { Gingival fibroblasts } \\
(n=9)\end{array}$} \\
\hline & & RA $(n=7)$ & $O A(n=9)$ & $J T(n=6)$ & & \\
\hline $\begin{array}{l}\text { Prolyl 4-hydroxylase } \\
\text { (intracellular) }\end{array}$ & $3-2 B 12$ & $92.9(2.0)$ & $96.8(1.0)$ & $99.6(0.2)^{*}+(n=5)$ & $97.6(0.5) \dagger \ddagger$ & $99.7(0.1)^{*} \dagger \S$ \\
\hline CD68 (intracellular) & $\mathrm{KP1}$ & $95.1(1.5)$ & $98.6(0.5) \dagger$ & $99.3(0.4) \dagger$ & $97.3(0.6) \ddagger$ & $99.8(0.0)^{*} \dagger \S$ \\
\hline CD68 (intracellular) & EBM11 & $93.5(2.4)(n=6)$ & $97.9(0.6)+(n=8)$ & $98.2(8.4)$ & $97.0(0.8)$ & $99.4(0.3)^{*}+\S^{* *}$ \\
\hline CD68 (intracellular) & PGM1 & $1.2(0.4)^{* * *}+\dagger$ & $1.4(0.2)^{* *}+\dagger$ & $0.9(0.2)^{* *}+\dagger$ & $1.1(0.5)^{\bullet * *}+\dagger$ & $0.9(0.1)^{* a^{* *}+\dagger}$ \\
\hline CD90 (surface) & $\mathrm{ASO} 2$ & 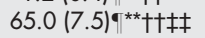 & 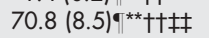 & $93.6(2.7)^{*}+{ }^{* *}+十 \ddagger \ddagger$ & 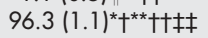 & $99.7(0.1)^{\star} \dagger \ddagger \S^{\star *}$ ††† \\
\hline
\end{tabular}

mAb, monoclonal antibody; RA, rheumatoid arthritis; OA, osteoarthritis; JT, joint trauma.

* $\mathrm{p} \leqslant 0.05$ Mann-Whitney U test versus OA SFB.

$t p \leqslant 0.05$ Mann-Whitney $U$ test versus RA SFB.

$\neq p \leqslant 0.05$ Mann-Whitney $U$ test versus JT SFB.

$\S p \leqslant 0.05$ Mann-Whitney $U$ test versus skin FB.

$\tau \leqslant 0.05$ Mann-Whitney $U$ test versus prolyl 4 -hydroxylase.

${ }^{* *} \mathrm{p} \leqslant 0.05$ Mann-Whitney $U$ test versus CD68/KP1.

$\dagger+p \leqslant 0.05$ Mann-Whitney $U$ test versus CD68/EBM1 1

$\ddagger \ddagger p \leqslant 0.05$ Mann-Whitney $U$ test versus CD68/PGM1.

Data are expressed as means (SEM).

contaminating leucocytes) SFB, skin FB, and gingival FB for CD68 upon intracellular staining (fig 3). In agreement with the primary localisation of CD68 in early and late endosomes, ${ }^{24}$ positivity may be expected in the intracellular compartment of FB. Therefore, to avoid false positive staining for CD68 in SFB, the analysis would have to be restricted to surface staining. As shown for the first time in surface staining of different FB populations, however, a low but considerable percentage of FB express CD68 molecules also on their surface (up to $7.5 \%$; table 7 ). This questions the universal use of CD68 as a $\mathrm{M} \phi$ marker, even in surface analysis of different cell populations.

Similar considerations apply to the identification of CD68 positive cells in synovial sections by IHC. Owing to the cutting procedure used to obtain cryostat sections, almost all cells can be assumed to expose their cytoplasm. The accessibility of the cytoplasm for antibody penetration is probably even increased in the case of acetone fixation (as used for the mAbs KPI and EBMIl). Indeed, unequivocal identification of $\mathrm{M} \phi$ and/or FB in tissue sections by CD68

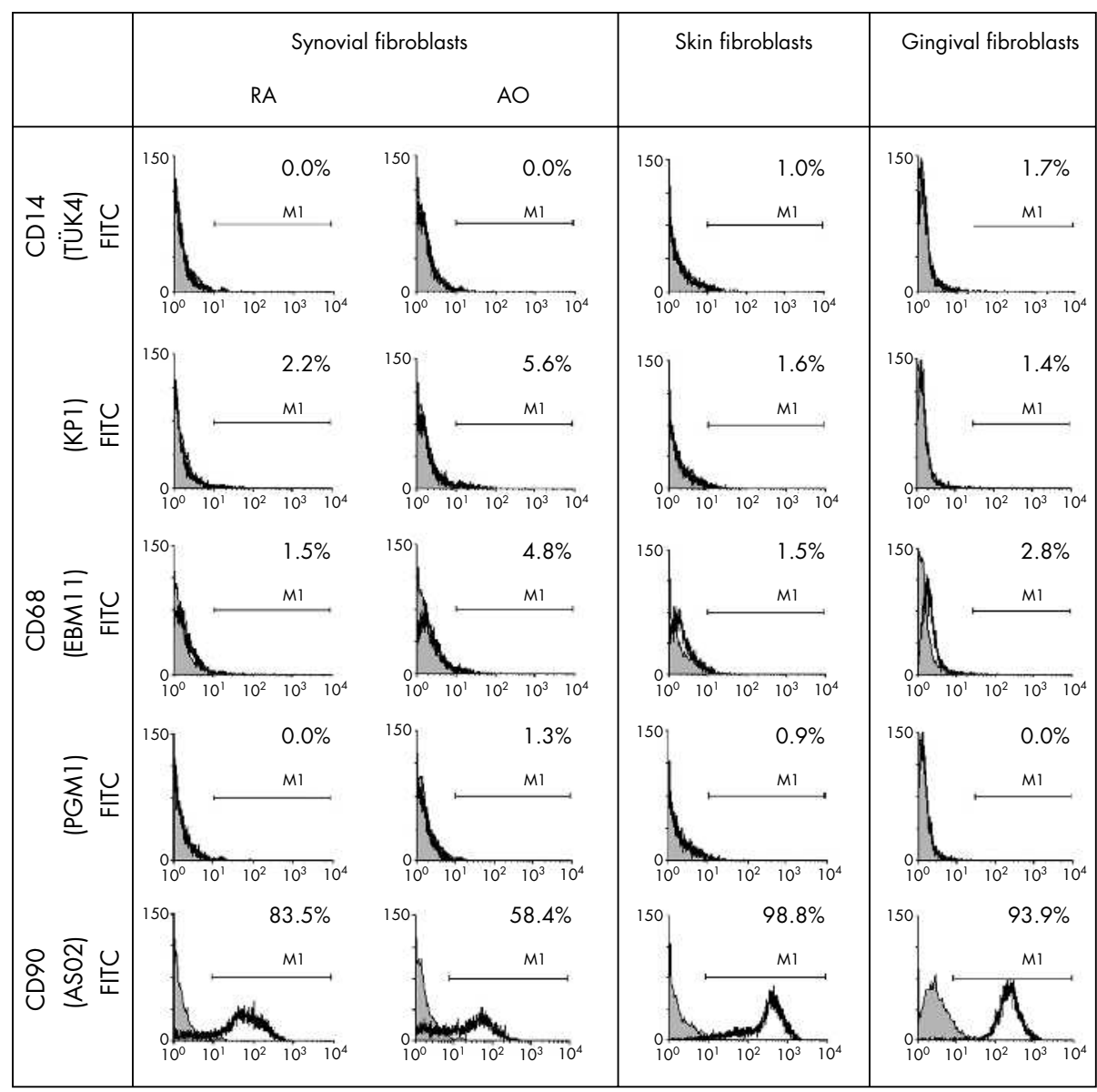

Figure 4 Flow cytometry analysis of RA SFB, OA SFB, and JT SFB, skin FB, and gingival $F B$ for surface expression of CD14, CD68 (mAbs KP1, EBM11, and PGMI ) and the FB marker CD90 (in each case, data from one representative experiment are shown). In surface staining experiments with unfixed RA SFB, OA SFB, skin FB, and gingival $F B$, only a small percentage of the cells stained positively for the three anti-CD68 mAbs KP1, EBM1 1, and PGM1. Almost no cells stained positively for the macrophage marker $\mathrm{CD} 14$, whereas the percentage of positive cells for the FB marker CD90 varied depending on the $\mathrm{FB}$ population (isotype control: shaded curve; specific antibodies: black line). 
Table 7 Percentage of $C D 68$ positive RA and $O A$ SFB, skin FB, and gingival $F B$ after surface staining of unfixed cells

\begin{tabular}{|c|c|c|c|c|c|}
\hline & \multirow[b]{2}{*}{$\mathrm{mAb}$} & \multicolumn{2}{|c|}{ Synovial fibroblasts } & \multirow{2}{*}{$\begin{array}{l}\text { Skin fibroblasts } \\
(n=5)\end{array}$} & \multirow{2}{*}{$\begin{array}{l}\text { Gingival } \\
\text { fibroblasts } \\
(\mathbf{n}=9)\end{array}$} \\
\hline & & RA $(n=4)$ & $O A(n=5)$ & & \\
\hline CD14 & TÜK4 & $0.9(0.1)$ & $0.8(0.1)$ & $1.2(0.2)$ & $2.0(0.5)^{*} \dagger$ \\
\hline CD68 (surface) & $\mathrm{KPl}$ & $5.4(1.1) \ddagger$ & $5.5(0.6) \ddagger$ & $1.3(0.1)^{*} \dagger$ & $1.7(0.3)^{*} \dagger$ \\
\hline CD68 (surface) & EBMI 1 & $4.3(1.1) \neq$ & $7.5(2.8) \ddagger$ & $1.3(0.1)^{*} \dagger$ & $2.3(0.5)^{\star}$ \\
\hline CD68 (surface) & PGMI & $2.1(0.9) 5$ & $1.0(0.1) \mp 5 \Phi$ & $0.8(0.1) \ddagger \S$ & $0.6(0.1)^{*}+\mp \delta 9$ \\
\hline \multicolumn{6}{|c|}{ 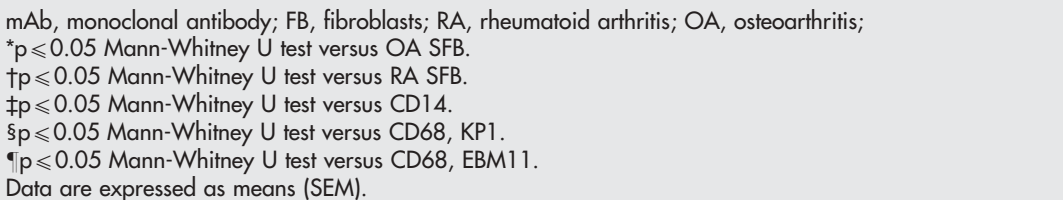 } \\
\hline
\end{tabular}

failed, as between $18 \%$ and $73 \%$ of the cells in different regions of the SM were positive for both CD68 and FB markers. In parallel with the findings in FACS analysis, staining with the different CD68 mAbs in IHC required differential pretreament of the sections. Whereas the mAb $\mathrm{KPl}$ and EBMll showed strong positivity in acetone fixed cryostat sections, staining with the mAb PGMl required prefixation with PFA and subsequent heating in SSC buffer (as used for the uncovering of antigen epitopes in paraffin sections for routine pathology). These findings further confirmed that the sensitivity of staining for CD68 with different mAbs depends on the pretreatment of tissue or cell samples. ${ }^{25}$

Taken together, although CD68 is widely used as a $\mathrm{M} \phi$ marker in immunohistochemical analysis and also in flow cytometry, the suitability/specificity of different CD68 antibodies to detect $\mathrm{M} \phi$ is questionable. This was demonstrated by (a) an overlap of the expression of CD68 and FB markers; (b) positivity of FB and activated endothelial cells for CD68; (c) a clear dependence of CD68 staining on the pretreatment of cells or tissue samples. Similar concerns apply to mAbs directed against MHC II molecules, strongly expressed on activated SFB in RA. ${ }^{21}$ The present report supports the view that CDI4 may be a more reliable marker of monocytes/M $\phi$, despite its potential down regulation on mature $\mathrm{M} \phi,{ }^{26}$ or else semispecific enzymes such as non-specific esterase. ${ }^{27}$ Further studies will have to demonstrate whether these conclusions not only apply to the advanced stages of RA analysed in the present study but also to samples from early synovitis, possibly with a less destructive phenotype.

\section{ACKNOWLEDGEMENTS}

Supported by the German Federal Ministry of Education and Research (BMBF; grants 01ZZ9602 and 01ZZ0105 to RW Kinne, Interdisciplinary Centre for Clinical Research (IZKF), Jena, and a grant for junior researchers to E Kunisch, IZKF, Jena) and the Thuringian Ministry of Science, Research, and Art (grant B311-00026 to RW Kinne).

Dr Sauer, plastic surgeon, Leipzig, Germany, and Dr Zielinski, oral surgeon in private practice, Jena, Germany, are gratefully acknowledged for providing the patient material; B Ukena and J Prechtel, Experimental Rheumatology Unit, Friedrich Schiller University, Jena, Germany, are gratefully acknowledged for technical assistance. Dr Ernesta Palombo-Kinne is gratefully acknowledged for critical revision of the manuscript.

\section{Authors' affiliations}

E Kunisch, R W Kinne, Experimental Rheumatology Unit, Friedrich Schiller University Jena, Jena, Germany

R Fuhrmann, A Roth, R Winter, Clinic of Orthopaedics, Friedrich Schiller University Jena, Jena, Germany

W Lungershausen, Department of Traumatology, Friedrich Schiller University Jena, Jena, Germany

\section{REFERENCES}

1 Kinne RW, Palombo-Kinne E, Emmrich F. Activation of synovial fibroblasts in rheumatoid arthritis. Ann Rheum Dis 1995;54:501-4.

2 Smith SC, Folefac VA, Osei DK, Revell PA. An immunocytochemical study of the distribution of proline-4-hydroxylase in normal, osteoarthritic and rheumatoid arthritic synovium at both the light and electron microscopic level. Br J Rheumatol 1998;37:287-91.

3 Saalbach A, Kraft R, Herrmann K, Haustein UF, Anderegg U. The monoclonal antibody ASO2 recognizes a protein on human fibroblasts being highly homologous to Thy-1. Arch Dermatol Res 1998;290:360-6.

4 Kraan MC, Haringman JJ, Post WJ, Versendaal J, Breedveld FC, Tak PP. Immunohistological analysis of synovial tissue for differential diagnosis in early arthritis. Rheumatology (Oxford) 1999;38:1074-80.

5 Micklem K, Rigney E, Cordell J, Simmons D, Stross P, Turley H, et al. A human macrophage-associated antigen (CD68) detected by six different monoclonal antibodies. Br J Haematol 1989;73:6-11

6 Kinne RW, Brauer R, Stuhlmuller B, Palombo-Kinne E, Burmester GR. Macrophages in rheumatoid arthritis. Arthritis Res 2000;2:189-202.

7 Mulherin D, Fitzgerald O, Bresnihan B. Synovial tissue macrophage populations and articular damage in rheumatoid arthritis. Arthritis Rheum 1996;39:115-24.

8 Kraan MC, Reece RJ, Barg EC, Smeets TJ, Farnell J, Rosenburg R, et al. Modulation of inflammation and metalloproteinase expression in synovial tissue by leflunomide and methotrexate in patients with active rheumatoid arthritis. Findings in a prospective, randomized, double-blind, parallel-design clinical trial in thirty-nine patients at two centers. Arthritis Rheum 2000;43:1820-30.

9 Barrera P, Blom A, van Lent PL, van Bloois L, Beijnen JH, van Rooijen N, et al. Synovial macrophage depletion with clodronate-containing liposomes in rheumatoid arthritis. Arthritis Rheum 2000:43:1951-9.

10 Wong P, Cuello C, Bertouch JV, Roberts-Thomson PJ, Ahern MJ, Smith MD et al. The effects of pulse methylprednisolone on matrix metalloproteinase and tissue inhibitor of metalloproteinase- 1 expression in rheumatoid. Rheumatology (Oxford) 2000;39:1067-73.

11 Greaves DR, Gordon S. Macrophage-specific gene expression: current paradigms and future challenges. Int J Hematol 2002;76:6-15.

12 Strobl H, Scheinecker C, Csmarits B, Majdic O, Knapp W. Flow cytometric analysis of intracellular CD68 molecule expression in normal and malignant haemopoiesis. Br J Haematol 1995:90:774-82.

13 Umino T, Skold CM, Pirruccello SJ, Spurzem JR, Rennard SI. Two-colour flowcytometric analysis of pulmonary alveolar macrophages from smokers. Eur Respir J 1999; 13:894-9.

14 Ramprasad MP, Terpstra V, Kondratenko N, Quehenberger O, Steinberg D. Cell surface expression of mouse macrosialin and human CD68 and their role as macrophage receptors for oxidized low density lipoprotein. Proc Natl Acad Sci USA 1996;93:14833-8.

15 Kivirikko KI, Myllyharju J. Prolyl 4-hydroxylases and their protein disulfide isomerase subunit. Matrix Biol 1998;16:357-68.

16 Hiraoka T, Izumi Y, Sueda T. Immunochemical detection of CD14 on human gingival fibroblasts in vitro. Oral Microbiol Immunol 1998;13:246-52.

17 Elner SG, Elner VM, Nielsen JC, Torczynski E, Yu R, Franklin WA. CD68 antigen expression by human retinal pigment epithelial cells. Exp Eye Res 1992;55:21-8.

18 Heinemann DE, Lohmann C, Siggelkow H, Alves F, Engel I, Koster G. Human osteoblast-like cells phagocytose metal particles and express the macrophage marker CD68 in vitro. J Bone Joint Surg Br 2000;82:283-9.

19 Wilkins BS, Jones DB. Heterogeneity of expression of CD68 and other macrophage-associated antigens in human long-term bone marrow culture. Biologicals 1996;24:333-7.

20 Arnett FC, Edworthy SM, Bloch DA, McShane DJ, Fries JF, Cooper NS, et al. The American Rheumatism Association 1987 revised criteria for the classification of rheumatoid arthritis. Arthritis Rheum 1988;31:315-24.

21 Zimmermann T, Kunisch E, Pfeiffer R, Hirth A, Stahl HD, Sack U, et al. Isolation and characterization of rheumatoid arthritis synovial fibroblasts from primary culture-primary culture cells markedly differ from fourth-passage cells. Arthritis Res 2001;3:72-6. 
22 Sack U, Stiehl P, Geiler G. Distribution of macrophages in rheumatoid synovial membrane and its association with basic activity. Rheumatol Int 1994;13:181-6.

23 Falini B, Flenghi L, Pileri S, Gambacorta M, Bigerna B, Durkop H, et al. PGM1: a new monoclonal antibody directed against a fixative-resistant epitope on the macrophage-restricted form of the CD68 molecule. Am J Pathol 1993;142:1359-72.

24 Rabinowitz SS, Gordon S. Macrosialin, a macrophage-restricted membrane sialoprotein differentially glycosylated in response to inflammatory stimuli. J Exp Med 1991;174:827-36.
25 Cuevas EC, Bateman AC, Wilkins BS, Johnson PA, Williams JH, Lee AH, et al. Microwave antigen retrieval in immunocytochemistry: a study of 80 antibodies. J Clin Pathol 1994;47:448-52.

26 Hogg N, Palmer DG, Revell PA. Mononuclear phagocytes of normal and rheumatoid synovial membrane identified by monoclonal antibodies. Immunology 1985;56:673-81.

27 Edwards JC, Wilkinson LS, Pitsillides AA. Palisading cells of rheumatoid nodules: comparison with synovial intimal cells. Ann Rheum Dis 1993;52:801-5.

\section{Clinical Evidence-Call for contributors}

Clinical Evidence is a regularly updated evidence based journal available worldwide both as a paper version and on the internet. Clinical Evidence needs to recruit a number of new contributors. Contributors are health care professionals or epidemiologists with experience in evidence based medicine and the ability to write in a concise and structured way.

\section{Currently, we are interested in finding contributors with an interest in the following clinical areas:}

Altitude sickness; Autism; Basal cell carcinoma; Breast feeding; Carbon monoxide poisoning; Cervical cancer; Cystic fibrosis; Ectopic pregnancy; Grief/bereavement; Halitosis; Hodgkins disease; Infectious mononucleosis (glandular fever); Kidney stones; Malignant melanoma (metastatic); Mesothelioma; Myeloma; Ovarian cyst; Pancreatitis (acute); Pancreatitis (chronic); Polymyalgia rheumatica; Post-partum haemorrhage; Pulmonary embolism; Recurrent miscarriage; Repetitive strain injury; Scoliosis; Seasonal affective disorder; Squint; Systemic lupus erythematosus; Testicular cancer; Varicocele; Viral meningitis; Vitiligo However, we are always looking for others, so do not let this list discourage you.

\section{Being a contributor involves:}

- Appraising the results of literature searches (performed by our Information Specialists) to identify high quality evidence for inclusion in the journal.

- Writing to a highly structured template (about 2000-3000 words), using evidence from selected studies, within 6-8 weeks of receiving the literature search results.

- Working with Clinical Evidence Editors to ensure that the text meets rigorous epidemiological and style standards.

- Updating the text every eight months to incorporate new evidence.

- Expanding the topic to include new questions once every 12-18 months.

If you would like to become a contributor for Clinical Evidence or require more information about what this involves please send your contact details and a copy of your CV, clearly stating the clinical area you are interested in, to Claire Folkes (cfolkes@bmigroup.com).

\section{Call for peer reviewers}

Clinical Evidence also needs to recruit a number of new peer reviewers specifically with an interest in the clinical areas stated above, and also others related to general practice. Peer reviewers are health care professionals or epidemiologists with experience in evidence based medicine. As a peer reviewer you would be asked for your views on the clinical relevance, validity, and accessibility of specific topics within the journal, and their usefulness to the intended audience (international generalists and health care professionals, possibly with limited statistical knowledge). Topics are usually 2000-3000 words in length and we would ask you to review between 2-5 topics per year. The peer review process takes place throughout the year, and our turnaround time for each review is ideally 10-14 days.

If you are interested in becoming a peer reviewer for Clinical Evidence, please complete the peer review questionnaire at www.clinicalevidence.com or contact Claire Folkes(cfolkes@bmigroup.com). 